\title{
AZ IMMATERIÁLIS ÉS A TERÜLETI TŐKE ÖSSZEFÜGGÉSEI
}

\author{
(Connection between Intangible and Territorial Capital)
}

\section{TÓTH BALÁZS ISTVÁN}

Kulcsszavak:

töke immateriális töke területi töke tökeátalakulások szükösség

A gazdasági tevékenység számára meghatározóak a termelési tényezök, különösképpen a tỏketényezök. A tóke fogalmával kapcsolatban a korai és modern szakirodalom számos meghatározást és megközelítést ad, mivel a különbözö közgazdasági iskolák teoretikusai az idök folyamán másként ítélték meg lényegét, illetve gazdaságban betöltött szerepét. Új tỏkefajták megalkotásával több tudományterület is aktivan foglalkozik az 1980-as évektöl, $s$ az egyre szélesedö palettân nagyarányban figyelhetö meg az immateriális töketípusok témyerése. Tanulmányunk célja egyrészt, hogy tisztább képet alkossunk a tökefajták körül uralkodó fogalmi zürzavarban a töketipusok elkillönitésével, másrészt, hogy meghatározzuk a teljes nemzetgazdasági tökeállomány és a napjainkban egyre divatosabbá váló területi töke metszetét. Írásunkban nagy hangsúlyt fektetünk a töke tágabb értelmezésére, a nem fizikai töketípusok egyéni és kollektív szintü halmazszerü elkülönitésére, a közöttïk megfigyelhetö tökeátalakulási folyamatokra, illetöleg ezek területi tökével való kapcsolódási pontjainak meghatározására. Tanulmányunk elkészítése sorân a szociológia és a pszichológia tudományteruiletein is ismeretes töketípusokat sem hagytuk figyelmen kívül, hiszen a tökekategóriák - különösen az immateriális típusúak - elsōgenerációs megalkotása nem mindig gazdaságelméleti alapú. Munkánk zárásaként kitérünk a szükösség és a területi kohézió fogalmának újraértelmezésére is.

\section{A tóke fogalmának fejlödése és a tỏkejavak tágabban értelmezett kategóriái}

A közgazdászok körében viszonylag nagy egyetértés van a tőke legszükebb, legfontosabb elemeket magában foglaló tartalmát illetően, de a tágabb értelemben vett, gyakran gazdasági értelmezésen is túlmutató tőke definiálása korántsem tünik egyszerü feladatnak. Hennings (1987) szerint, ha a közgazdászok egyet fognak érteni a tőke elméletét illetően, akkor nagy valószínüséggel minden másban is egyetértenek majd.

A közgazdasági elméletek megszületésétől fogva nagy viták folynak a tőke értelmezése körül. A fogalom túlságosan tág, és napjainkban is tovább szélesedik. Az egyes tőkekategóriák beltartalma viszonylag jól kidolgozott, azonban mérhetőségi feltételeinek kimunkálása még sok kívánnivalót hagy maga után. Az új keletü tőkeelemek a jelenlegi közgazdasági eszközrendszer figyelembevételével alkalmatlanok vagy pontatlanok a megfelelő megbízhatóságú mérésre, s nem is lehet őket teljességében megragadni. Jelentős problémák vannak a tőke aggregálhatóságával, mivel a tőkejavaknak nincs közös természetes mértékegysége. Az alábbiakban röviden a tóketényezővel kapcsolatos főbb nézeteket, elméleteket tekintjük át, melyhez 
Mátyásnak (1973; 2004a; 2004b), Linnek (2001) és Storbergnek (2002) a közgazdaságtan elmélettörténetéröl, illetőleg tőketörténetéről szóló munkáit használjuk fel.

A tőke fogalmát és annak gazdaságban játszott szerepét különbözőképpen értelmezték a klasszikus, de még a polgári közgazdaságtan úttörői is. A korai és klasszikus közgazdászok, követőik, illetỏleg bírálóik - Petty, Quesney, Turgot, Smith, Ricardo, Mill, McCulloch, Say, Marx stb. - vitája arról szólt, hogy a tỏke a munkával és a földdel egyenrangú termelési tényező-e. Filozófiájukban főként a tôkés és munkás, a gép és a munka, illetve a profit és a munkabér közötti állandó verseny kapott jelentősebb szerepet. Általában a többi termelési tényezöhöz viszonyítva értekeztek a tőke szerepéről, de foglalkoztak a tőke egyes típusainak - pénztőke, befektetett tőke, állótőke - részletesebb vizsgálatával is.

A modern polgári közgazdaságtan nyitott új fejezetet a fogalom értelmezésében (Lin 2001). A termelés modern elméletének köszönhetően a tőke a 20. század első harmadában vált végérvényesen önálló és független tényezövé a termelési függvényben (a munka és a föld mellett). A keynesi fordulat eredményeképpen a tökét, mint beruházásokat ösztönzö tényezőt definiálták (Mátyás 1973), s ez a felfogás később kiváló alapjául szolgált mind a neoklasszikus, mind a keynesi alapokra épülő növekedési modelleknek. A monetarista forradalom a tőke fogalmán, annak tartalmán érdemben nem változtatott.

Storberg (2002) tőketörténeti munkájában a közgazdaságtant és a politikatudományokat tekinti át a kezdetektől napjainkig. A klasszikus tőke korszakának áttekintése Storberg (2002) vizsgálataiban a 19. század közepének elemzésével kezdődik, de a neoklasszikus közgazdaságtant átugorva az 1960-as évekre helyezi a fö hangsúlyt, s a Schultz által definiált emberi tőke fogalmáról - mint az újtőke elméletek korszakának kezdetéről - értekezik részletesebben. Storberg (2002) a tőke fogalmának történeti elemzéséböl fontos következtetést von le. Megállapította, hogy a nagyobb aggregátumokra, a közösségre értelmezhető tőkekategóriák rovására egyre inkább szaporodnak az egyénekhez kapcsolható tőkefogalmak, amely azt jelenti, hogy a tőketípusok tartalma egyre inkább az egyedi sajátosságra vonatkozik, s nem kollektív ismérvekre.

Lin (2001) még részletesebben mutatja be az újtőke koncepciót. A tőke történetét két szakaszra tagolja, megkülönbözteti a klasszikus és az újtőke korszakát. Az előző kategóriába csak a kézzel fogható elemeket sorolja, a másodikba olyan, kézzel nem fogható jelenségeket is besorolt, mint a vállalatok számolatlan vagyonállománya, a tudásmenedzsment, az információkezelés vagy a személyes kapcsolatok. Lin (2001) feltételezi tehát, hogy a tudásgazdaság egyeduralkodóvá válása és a megállíthatatlan, egyre gyorsuló információs technológiai változások időszakában az újtőkék fontossága egyre nagyobb lesz. A menedzsmenttudomány, illetve a szociológiai és pszichológiai tudományok által definiált tőkeelemek - intellektuális tőke, szellemi tőke, társadalmi tőke, kulturális töke, szimbolikus tőke, pszichikai tőke stb. - az 1970-es és 1980-as évektől kerülnek fokozatosan a kutatások középpontjába, majd a köztudatba. A 21. században, az ezredforduló tudásalapú társadalmában már egyre gyakrabban hallani a tudástóke, kreativitás tőke és tudattőke kifejezéseket is, a regionalizáció 
erősödésével pedig egyre szélesedő körben figyelhető meg a területi tőke fogalmának használata. Az újtőke kategóriák tartalma azonban napjainkig még nem egységesült.

A vállalat- és nemzetgazdaságok tőke- és vagyonállományának feltérképezése lényegében az ezredforduló előtt került az új szemléletủ elemzések körébe, miután a vállalatok számolatlan vagyonának leírása, illetőleg mérése a közgazdasági kutatások egyik fö csapásirányát jelölte ki. A nyolcvanas években megváltozott a gazdálkodó egységek belső eszközeiről alkotott értékítélet, mivel számos szervezet versenyképességében sokkal lényegesebb szerepet játszik annak alkalmazkodóképessége, kultúrája és magkompetenciája (Hamel-Prahalad 1990). Hamel és Prahalad (1990), illetőleg követőik munkássága nyomán a vállalati szférában egyre szélesebb körben jelentek meg a kevésbé fizikai tőkeelemekkel foglalkozó publikációk (Skandia 1995; Sveiby 1997), napjainkig azonban még nem sikerült a nemzetgazdaságok számolatlan, megfoghatatlan (intangible capital), láthatatlan vagyonelemeinek (invisible capital) egységes feldolgozása (OECD 1996; 2001a; 2001b; Worldbank 2006).

A közgazdászok már régóta elkülönítik az elöállított vagy termelt tőkét (produced capital), a nominális vagy pénztőkét (financial capital), a reáltőkét vagy beruházását (investment capital) - melyek közös jellemzője, hogy jól mérhető típusok, s egy adott terület vagy ország bruttó hazai, illetőleg nemzeti termékében könnyen kifejezhetők -, de ezen túlmenően meghatározhatók immateriális elemek is. Ide sorolható az intellektuális vagy szellemi tôke (intellectual capital), a humán tőke (human capital), a szervezeti tőke (organizational capital), a strukturális tőke (structural capital), illetve a személyfüggő és személyfüggetlen kapcsolati töke (relational capital). A szociológia tudománya a társadalmi tőkét (social capital), a kulturális tőkét (cultural capital), illetöleg az ezek továbbörökítését biztosító szimbolikus tőkét (symbolical capital) emlegeti gyakorta. A pszichológia területéröl elsősorban a pszichikai töke (psychical capital) fogalma emelhetö ki.

\section{Intellektuális/szellemi töke}

Mivel a vállalati gazdaságtan és számvitel a láthatatlan vagyonállomány leírásának és mérhetövé tételének területén a közelmúltban nagy előrehaladást tudott felmutatni, ezért a láthatatlan értékek megragadását érdemes erröl az oldalról kezdeni. A nemzetközi kutatásokban néhány évtizede jelent meg az a nézet, mely szerint a vállalatok piaci és könyv szerinti értéke között eltérés mutatkozik, $\mathrm{s}$ a mai vállalatok piaci értékének nagyobb részét nem is a könyv szerinti értékük teszi ki (Sveiby 1997). Az eltérés az ún. intellektuális tőkének, más néven a szellemi tőkének köszönhetö. Az említett két tőketípus közé lényegében egyenlöségjel húzható az elméletben, közöttük csupán a magyar fordítás tesz apróbb különbséget. Az intellektuális tőke kifejezést Galbraith már 1969-ben használta, de a fogalmat nyilvánosan csak az 1990-es években publikálta elöször a Skandia kutatócsoport (Skandia 1995), majd Stewart (1997). Az intellektuális töke beltartalma nem írható le egységesen, de a témával foglalkozó kutatók, elemzők nézetei alapvetően három területre vonatkoznak: humán területek, szervezetek területe és kapcsolatok területe. 


\section{Humán területek: humán tỏke, kreativitás tőke, pszichikai tỏke, tudástöke}

Az emberi tőke elmélet megalkotója, Schultz (1983) szerint az emberek kiadásainak jelentôs része nem más, mint az emberi tőkébe való beruházás, melynek eredménye a munkaerő minőségének javulásában testesül meg. Schultz (1983) elismerte, hogy a szerzett ismeretek a befogadó személy részévé válnak, azaz emberi tőkévé alakulnak. Machlup (1982) értelmezése szerint az emberi erőforrás csak akkor minősül tőkének, ha termelőképességének fenntartása, illetve javítása érdekében pótlólagos beruházásokat végeznek rajta. Machlup (1982) a személyekbe fektetett beruházásoknak csak az emberbe épített, attól elválaszthatatlan eredményét tekintette emberi tőkének, s megfogalmazta, hogy nem minden tudásnövekedés emberi tőkenövekedés, illetőleg nem minden emberi tőke-növekedés tudásnövekedés. A leírt, dokumentumokban megörökített tudás nem feltétlenül növeli az emberi tőkét, ugyanakkor az emberi tőke egyes formái (pl. migráció, egészségbe fektetett befektetések stb.) nem a tudás állományát gyarapítják, hanem az emberek teljesítményét fokozzák. Ebben az esetben tehát nem az emberek intelligenciája, az emberi és az intellektuális tôke mennyisége növekszik, hanem a klasszikus értelemben vett munkajavak nagysága. Az OECD (1996; 2001a) meghatározása szerint humán tỏkének minősül az egyénekben beágyazódott tudás, a szakértelem, a hozzáértés, egy adott tevékenység végrehajtására való képesség, amely megkönnyíti az egyéni, társadalmi és gazdasági jólét megteremtését.

Markman (2007) szerint az egyénnek a tudáserőforrás-kezelés sajátos készségére is szüksége van a tudás birtoklásán túlmenően. Feltételezi egy olyan jelenség hatását is, amely pszichikai tökének vagy tökehasználati képességnek nevezhető. Markman (2007) megközelítésében ez a készség magában foglalja többek közt a tudás megszerzéséért befektetett energiát, az érzelmi intelligenciát, a kifejezökészséget, az önkontrollt, illetve az alkalmazkodó-készséget. Az egyén, aki a műveltség megszerzésén dolgozik „önmagán dolgozik, önmagát müveli” (Bourdieu 1983, 186). A folyamatos tanulás és tapasztalatszerzés az egyének számára lehetővé teszi, hogy szakemberekké váljanak, s innovatív ötleteikkel, gondolataikkal, új összefüggések meglátásával ráébredjenek találékonyságukra, kreativitásukra. A humán és pszichikai tőkével tehát egyfajta kreativitás tőke is párosul, melynek felhalmozódását egy elsajatítási folyamat előzi meg, így a kreativitás kibontakozása elsősorban képzési és tanulási idôt igényel.

Stehr (2002) nyomán még egy tőketípust meg lehet különböztetni a humán területeken, mégpedig a tudástőkét. A tudástőke annyiban több mint a humán tőke, hogy a cselekvés képességét hangsúlyozza, melyben benne foglaltatik a kreativitás és a tőkehasználati képesség is. A tudásalapú társadalom gazdaságát nagyrészt nem az anyagi, hanem a szimbolikus vagy a tudásalapú bemenetek hajtják, ahol nagy számban találhatók olyan szakmák, amelyek a tudással való foglalatosságot foglalják magukban, és csökkenő számban találhatók olyan munkahelyek, amelyek alacsony kognitív képességet igényelnek, mint amilyen a gyártásban található (Stehr 2002). 


\section{Szervezetek és kapcsolatok területe: strukturális tőke, szervezeti töke, kapcsolati tỏke}

A strukturális tőkével kapcsolatban változatos elnevezések és tartalmak figyelhetők meg a témával foglalkozó szakirodalomban, így egyértelmủ részelemmel nem igazán találkozhatunk. Egyes kutatók - mint a Skandia kutatócsoport (1995) vagy Sveiby (1997) - a szervezet és kapcsolatok területét együttesen strukturális tőkeként definiálják, s a humán területek, illetve a strukturális területek uniójaként fogják fel az intellektuális tőkét. Mások - mint például Stewart (1997), illetôleg Edvinsson és Malone (1997) - viszont kizárólag a szervezetek területére használják a strukturális tőke kifejezést. Az általunk követett felosztás a Skandia-féle megközelítéssel nagyrészt megegyezö, azzal a kikötéssel, hogy a kapcsolatok rendszeréből csak a kollektív kapcsolatokat tekintjük a strukturális tőke részeként, az egyéni kapcsolatok rendszerét nem.

A szervezeti tőke fogalma Tomer munkásságához vezethető vissza, aki 1973-ban doktori disszertációjában említette a fogalmat, majd a témával kapcsolatban később több tudományos publikációt is megjelentetett. A szervezeti tôke olyan elemek öszszessége, amelyek a szervezet korábbi müködésének eredményeképpen jöttek létre (Tomer 1987), és nem személyhez kötöttek, mint például a fentebb bemutatott humán tôke. Két fö elemeként említhetô a szervezetek számviteli immateriális javai mint az alap- és alkalmazott kutatás, a fejlesztések eredményei, illetve a saját fejlesztésủ eszközök értéke, az értékes, már bevezetett márkanév -, illetőleg infrastrukturális eszközök - így a vezetés filozófiája, a szervezeti kultúra, formális és informális információs és kommunikációs rendszerek, kapcsolatok, befektetői, pénzintézeti és egyéb hálózatok.

Tomer (1987) szerint a szervezeti tőke mennyisége úgy növekszik, hogy egy szervezet racionális szervezetfejlesztési beruházásokat hajt végre. A beruházások keretében a szervezet tagjai racionalizálhatják a formális és nem formális kapcsolati rendszereket, illetőleg a vállalati múködés mintáit, továbbá megváltoztathatják az egyén hozzáállását, viszonyulását a szervezethez, esetleg ösztönözhetik a jobb információáramlást. A szervezeti tỏkébe történő beruházás fokozza a termelékenységet, emeli az alkalmazottak jólétét, $\mathrm{s}$ hozzájárul a szervezeti légkör javulásához is. A szervezetfejlesztésben óriási szerepe van a szervezeti és vállalkozói képességeknek, melyek az egyének képességeiböl fakadnak. A szervezet tagjainak tudása, humán potenciálja összeadódik egyfajta vállalkozói szolgáltatássá, amely nem az egyes egyének humán tőkéjét növeli, hanem a kollektív szervezeti tőkét. Ez az eröforrás különleges szerepet tölt be, mert összeköttetést biztosít a humán és szervezeti tỏkeelemek között. A szervezeti tôke nagysága a vállalkozói képességek áttételes hatásán keresztül végeredményben a humán tỏkébỏl táplálkozik.

A kapcsolati tóke lehet az ember és a szervezet sajátja is. A szociálpszichológia oldaláról közelítve kapcsolati tőkével az egyének rendelkeznek, a gazdálkodástudományokban viszont a gazdálkodó külsö kapcsolatrendszerekben rejlö eröforrásokat (vevők, hálózatok, klaszterek, $\mathrm{K}+\mathrm{F}$ intézmények stb.) lehet illetni a kapcsolati 
töke elnevezéssel. Lényeges tehát annak megkülönbözetése, hogy a kapcsolatok személyhez kötődnek vagy személyfüggetlenek. A különböző cégek és intézmények vezetỏi, alkalmazottai közötti kapcsolatok személyfüggők, míg a vállalatok és közintézmények, konkrét szervezetek viszonylatában már személyfüggetlenek (Sprenger 2001), s inkább az adott intézmény strukturális tökéjét gazdagítják (befektetöi, pénzintézeti és egyéb hálózatok). Capello és Faggian (2005), illetve Camagni (2008) meghatározása alapján kapcsolati tőkének tekinthetjük a gazdaság egyes szereplöi közötti együttmúködéseket, sôt a tudástranszfert és tapasztalatcserét is, nemcsak vállalati szinten, hanem országok, régiók és települések között is. A kapcsolati tỏke tehát egyfajta képesség a közös célok elérése érdekében való együttmüködésre, bizalmi tỏke is egyben (Capello-Faggian 2005). Nagysága azon kapcsolatok hálójának kiterjedésétől függ, amelyeket ténylegesen mozgósítani tud a gazdálkodó vagy a szervezet. A kapcsolatok generálásával olyan innovatív hálózatok jönnek létre a gazdálkodó szervezetek között, amelyek minimalizálják a jó tapasztalatok egyéni átvételéből fakadó gyengeségeket. A tudás- és kapcsolatigényes fejlődés olyan stratégiát alakít ki, amely effektív információs infrastruktúrával bír és hálózatépítést generál. A kapcsolatháló azoknak az egyéni vagy kollektív beruházási stratégiáknak a terméke, amelyek tudatosan vagy öntudatlanul olyan együttmüködés megteremtésére irányulnak, amelyek előbb-utóbb közvetlen haszonnal kecsegtetnek (Capello-Faggian 2005; Camagni 2008).

\section{Kulturális töke}

A társadalmi státuszokat és pozíciókat a kulturális tőke birtoklása, annak megoszlása határozza meg. A kulturális tőke sokrétủen kötődik a személyhez, annak biológiai egyedülvalóságához és állapotához, az egyén személyes képességeihez és egészségi helyzetéhez. Bourdieu (1983) tanulmányában a kulturális tőke három fajtáját különböztette meg. Az ún. inkorporált kulturális tőke a tartós készségek formájában létezik, alapvetően testre szabott és bensővé tételt tételez fel. A felhalmozást egy elsajátítási folyamat előzi meg, amely képzési és tanulási időt igényel, s ahol az idôt személyesen kell beruházni (Bourdieu 1983). A bensővé tett kulturális tőke elsajátítása - koroktól, társadalmaktól és társadalmi osztályoktól függően különbözö mértékben mehet végbe. A kulturális tőke inkorporált formája mindig rejtett, gyakran teljesen láthatatlan marad (Bourdieu 1983). Az inkorporatív állapotban lévő kulturális tőkét a továbbiakban az egyéni tudástőkével azonosítjuk.

Az ún. objektivált kulturális tőke - a kulturális tôke második formája - materiálisan adható át. A felhalmozott tudást és az egyének kreativitásának termékét anyagi hordozók - kodifikált írások, képzőmüvészeti alkotások, termékek, technikák stb. révén teszik láthatóvá. Létrehozásához inkorporált kulturális tőkére van szükség. Minél több az anyagi hordozó (pl. egy adott téma kutatásában publikált cikk, könyv vagy egy adott eljárás kifejlesztése során létrehozott találmány, új technológiai 
vívmány, innováció stb.), annál nagyobb esélye van az egyénnek intézményesíteni kulturális tókéjét. A kulturális tőke birtoklása ugyanis társadalmi státuszt biztosít az egyén számára, esetenként a társadalmi pozíciót határozza meg. Az iskolai végzettség, a tudományos fokozat vagy a munkahelyen betöltött pozíció intézményes elismerést kölcsönöz az adott személy által birtokolt kulturális tőkének.

\section{Társadalmi töke}

A keynesiánus közgazdaságtan, majd később a szociális piacgazdaság koncepciója felismerte, hogy jól müködő piacok nem maguktól léteznek, a piacgazdaságoknak ugyanis szüksége van jogi keretekre, intézményekre. A formális és informális intézmények figyelembe vétele egy olyan fogalom által történik újabban, amely eredetileg a szociológiából - és a politikatudományból - származik: társadalmi tőke. A fogalmat a nyolcvanas években alapozta meg Bourdieu, de igazán népszerúvé Coleman, majd Putnam olasz és amerikai társadalmi tőkéről szóló mủveivel vált. A működőképes gazdasági és politikai rendre gyakorolt jelentősége miatt a társadalmi tőke fontos szerepet játszik a fejlesztések gazdaságtanában, valamint a nemzetközi szervezetek politikájában (ez utóbbi kapcsán a Világbank 2006-ban kiadott Where is the Wealth of Nations? c. tanulmánya emlithetö).

A társadalmi tőke Bourdieu (1983) szerint olyan erőforrás, amely az egy csoporthoz való tartozáson alapul. Bourdieu (1983) világossá teszi, hogy az egyén által birtokolt társadalmi tőke nagysága azon kapcsolatok hálójának kiterjedésétől függ, amelyeket ténylegesen mozgósítani tud. A társadalmi tőke újratermeléséhez elengedhetetlen a folyamatos kapcsolattartás, amely idöbe és pénzbe kerül (fizikai, gazdasági tỏkét feltételez), illetőleg szükséges hozzá egy olyan képesség, amely felismeri és kihasználja a kapcsolatokat. Coleman (1988) tanulmányaiban is megjelennek a tőke különböző fajtái, formái; így megkülönböztetett pénztőkét, tárgyi tőkét, emberi és társadalmi tỏkét, $\mathrm{s}$ ez utóbbi - mint cselekvést elősegítő erőforrás - a társadalmi struktúra bevezetését jelenti a racionális döntések paradigmájába. Elméletében a társadalmi tőke a társadalom tagjai közötti kapcsolatok struktúrájában jelenik meg. Putnam (1993) szerint a társadalmi tőke közjószág, ami azt jelenti, hogy nem személyes tulajdona azoknak, akiknek a hasznára válik, illetve általában nem magánszemélyek biztosítják. A társadalmi tőke tipikusan kötelékekből, normákból, bizalomból és intézményekből áll össze, amely átvihető egyik társadalmi környezetből a másikba. A „civil erényként” is definiálható társadalmi tóke az egyének közötti kapcsolatokra, a kapcsolatokból felépülő hálózatokra és a hálózatokat múködtetó generalizált és specializált közösségi elvekre is utal (Putnam 1993). Fukuyama (2007) értelmezésében a társadalmi tőke lehet magánjószág. A társadalmi töke akkor jelenik meg mint egyéni jellemzö, ha az egyén képes arra, hogy hatékonyan érvényesítse és mozgósítsa azon társadalmi összeköttetéseit, amelyek kölcsönösen hasznos cserére és viszonosságra épülnek. Fukuyama (2007) a hangsúlyt az együttmüködésre és a mozgósításra helyezi. 


\section{Szimbolikus tőke}

Stehr (2002) munkájában kiemelte, hogy a tudás nem egyszerüen valamilyen információtár, hanem az információ cselekvéssé válása. Ha a társadalomban az információ objektiválásra, a tudás alkalmazásra kerül, akkor a tudás- és kulturális tőke átalakul, és jeltókévé válik. Az egyén számára a jelek halmaza adja a világról, társadalomról, annak müködéséről alkotott képet. Ezt a jelenséget illetjük a tudattöke elnevezéssel. Az anyagi hordozókban az objektivált közleményen keresztül különböző érzéseket, hangulatokat, egész gondolatsorokat is fel lehet idézni (Stehr 2002). Ha az egyes jeltőkéket a generációk továbbörökítik, akkor kollektív szinten növelik annak állományát. Koncepciónkban a jeltőke összességét nevezzük szimbolikus tőkének.

A szimbolikus tőke ,a gazdasági és a fizikai töke átalakított és ezáltal álcázott formája" (Bourdieu 1978, 399), amely a gazdasági, a kulturális és a társadalmi tőke birtoklását és továbbörökítését biztosítja. A szimbolikus tókében áramlik egymásba a történelem során felhalmozott összes materiális, de főként az összes intangibilis tỏkeelem. A materiális és a szimbolikus vonások szerves összefüggésben állnak (Bourdieu 1983). Egy adott nemzet történelmében, kultúrájában, vallásában, irodalmában, képzőművészetében rejlik a szimbolikus tőke titka, s az anyagi hordozók pedig - mint a hagyományok felelevenítése, az ünnepek, a fesztiválok, a ceremóniák, a vallásgyakorlás, az irodalmi és a képzőmüvészeti alkotások stb. - ezeket a szerves termékeket, sajátos atmoszférát objektiválják. Az anyagi hordozók tartalmát, azaz a gazdasági és fizikai tőke formáit mindenkinek egyénileg kell megtapasztalnia, hiszen az ezekkel kapcsolatos érzések személyfüggők. Mindnyájunkban más gondolatokat és érzéseket ébresztenek az egyiptomi piramisok, a görög és római templomok, a reneszánsz freskók, a barokk kertek, a klasszicista zenemúvek, a romantikus versek és a felsorolás még hosszan folytatható lenne. Ezen túlmenően szimbolikus tőkét hordoznak magukban a természeti értékek is (pl. a holland zöldmezők, a doveri fehér sziklák, az izlandi gejzírek, vagy akár a magyar puszta).

A különbözố tôketípusok - gazdasági, társadalmi, kulturális - szimbolikus tőkévé konvertálása idő- és munkaigényes folyamat. Felhalmozása azonban nem elhanyagolható, mert a jeltőke nagymértékben növelheti a nemzetgazdaság láthatatlan tôkeállományát. Hosszú távon valójában ez szolgál egy nemzet, egy ország vagy egy országon belüli területi egység jövőbeni sikerének alapjául. A szimbolikus tőke fontossága abban rejlik, hogy megfelelő akciókkal visszaalakítható gazdasági, azaz fizikai tőkévé. Ebben a folyamatban nagy szerepe van a megfelelö promóciós stratégiáknak.

\section{Területi tôke}

A területi tỏke (territorial capital) fogalmát legelöször 2001-ben az OECD Territorial Outlook címú regionális politikáról szóló írása említi, késóbb a fogalmat az Európai Unió gyakorlata is átvette (OECD 2001b). A területi tőke nem illeszthető 
be az elöző kategóriák egyszerü folytatásaként. A tanulmány eddig tárgyalt alpontjaiban az egymás mellett létező immateriális tőkeelemeket különítettük el, a területi tőke viszont vertikálisan metszi keresztül ezeket. A területi tőke alkotóelemeinek tárgyalásánál két nagyobb felosztást lehet megkülönböztetni. Az egyik megközelítés az OECD nevével fémjelezhetö, míg a másik, tudományosabb alapokra épüló koncepció Camagni munkásságához kapcsolódik.

Az OECD (2001b) összeállított egy terjedelmes listát, amely a területi tókét meghatározó tényezőket veszi számításba. Ez tartalmazza a hagyományos anyagi eröforrásokat és a legújabban feltárt nem anyagi jellegú eröforrásokat egyaránt $(O E C D$ 2001b):

- a terület földrajzi elhelyezkedése, helyzete, nagysága, adottságai, éghajlata, természeti eröforrásai, termelési lehetőségei;

- a terület életminösége, városainak agglomerációs gazdasága, üzleti tevékenységére pozitívan ható ipari körzetei, a tranzakciós és szállítási költségeket csökkentö üzleti hálózatai;

- a terület jellemző hagyományai, szokásai;

- nem közvetített kölcsönös függöségek: befogadókészség, a gazdasági szereplök együttműködését elősegítő informális szabályok (melyek képessé teszik a gazdaság szereplöit az együttmüködésre bizonytalan helyzetekben is);

- kölcsönös segítségnyújtás és szolidaritás (melyek gyakran az ugyanabban a szektorban müködő kis és középes nagyságú vállalkozásokban fejlődnek ki);

- a terület kis- és középvállalkozásainak hálózatai, klaszteresedés;

- a területen található formális intézmények, azok szabályai és gyakorlata;

- továbbá a helyi termelők, kutatók és politikusok kombinációja, egyuittmúködése.

A területi tỏke meghatározásával Camagni tanulmányai is részletesen foglalkoznak, aki klasszifikációjában az alábbi kategóriákat különítette el (Camagni 2008):

- helyhez kötött külső tényezők rendszere, pénzügyi rendszerek (ahol a kedvező hatások a piaci tranzakciókon keresztül érvényesülnek) és technológiai rendszerek (ahol a kedvező hatásokat a források közelsége jelenti);

- helyi termelési tevékenységek rendszere és a hozzájuk kapcsolódó hagyományok, szakértelem, tudás, know-how;

- helyi szomszédsági kapcsolatok rendszere, amely kedvező szociális, pszichológiai és politikai hátteret biztosít, fokozva a helyi tényezők statikus és dinamikus termelékenységét;

- helyi kulturális értékek rendszere, amely értelmet ad a lokális gyakorlatnak és struktúráknak, kiemeli azok jelentőségét, egyszersmind meghatározza a helyi identitásokat;

- helyi irányítási modellt meghatározó szabályrendszerek és a helyi önkormányzatok gyakorlatának rendszere.

Az OECD általi felosztás és Camagni meghatározása lényegében az anyagi és az összes fentebb bemutatott immateriális tőkeelemet érinti. A területi tőke különlegessége, hogy kifejezésre jut benne a különbözö földrajzi területek közötti távolság 
úgy, hogy az adott térségben élö beruházók magasabb megtérülési követelményt támaszthatnak beruházásaikkal szemben, mint az adott térségen kívül élők. Egy beruházás megtérülése ugyanis nagymértékben függ attól a helytől, ahol a beruházást végrehajtották, mivel a megtérülési ráta gyakorta változik egyik területrỏl a másikra. A helyi gazdaság szereplői jobban ismerik a szóban forgó térség gazdasági folyamatait, s hatékonyabban tudják használni eszközeiket, vagyontárgyaikat és erőforrásaikat (OECD 2001b; Camagni 2008), így magasabb megtérülési követelményt támaszthatnak. Ebben a megközelítésben a régiók nem a ricardoi komparatív előnyök elve alapján versenyeznek egymással, hanem sokkal inkább a Smith által képviselt abszolút előnyök játékszabályai szerint.

A területi tőke fontosságát akkor ítélhetjük meg helyesen, ha az ún. Catin-féle hatásokat is figyelembe vesszük. Catin (2000) szerint egy beruházás végrehajtásának különböző hatása van az egyes területeken. Catin (2000) három típust különböztet meg: multiplikátor-hatás, termelékenység-hatás és versenyképesség-hatás. A multiplikátorhatás egyrészt utal a termelők kínálatának és a fogyasztók keresletének, másrészt a növekvő regionális jövedelmek túlcsordulására is. A spillover hatások a fenti felsorolásban szereplö regionális jellemzőktől nagymértékben függnek, de szerepet játszik a helyi fogyasztásra és a térség gazdasági nyitottságára vonatkozó határhajlandóság is. A termelékenység-hatás a beruházások által indukált növekvő méretgazdaságosságból és az agglomerációs gazdaságból vezethető le. A versenyképesség-hatást az alacsony import vagy a magasabb export generálja, ugyanis ekkor feltételezhetö, hogy a helyi termelés minősége javult, s lehetőség nyílik a behozatal csökkentésére, illetöleg a kivitel növelésére (Catin 2000).

A vázolt hatások tehát a beruházás által érintett terület speciális jellemzőitöl függnek. Ezek a speciális jellemzők a vázolt tőkekategóriákon belül gyökereznek. Nagy hatással van a régió területi tőkéjének nagyságára, hogy az egyes társadalmakat, kultúrákat mennyire érezzük közelebbinek vagy távolabbinak. A naprakész és innovatív tudás, a kreativitás, a gyakori kommunikáció, a hálózatépítés, a több és pozitív információ, a racionalizált szervezet és a többi immateriális tényezö ugyanis csökkenti a régiók közötti kognitív (elképzelésbeli) távolságot. A közelségböl fakadó helyismeret mérsékli a bizonytalanságot, s megkönnyíti a döntéshozók munkáját a befektetésekkel kapcsolatos kérdéseket illetően. A területi tőke elemei nyereséghez, haszonhoz, s különféle előnyhöz vezetnek. Ha egy átlagos szinttől elmaradott régió kihasználja a területi tőkében rejlö potenciálokat, akkor lehetővé válik számára olyan tevékenységek fejlesztése, melyek abszolút előnyhöz vezetnek, és rentábilisabbak lesznek, mint addig voltak (OECD 2001b).

$\mathrm{Az}$ előző pontokban ismertetett tőkekategóriákat mutatja be rendszerbe foglalva az 1 . és a 2. ábra. Az 1. ábra egyéni és kollektív szinten mutatja be a fentebb érintett tőketípusokat és a tőkeátalakulás folyamatait. A 2. ábrán szereplő halmazokon belül a felsỏ indexszálás jelenti az egyes területek vagy régiók egyes tỏketípusokon beluuli állományát. 
Tóth Balázs István : Az immaterális és a területi tőke összefüggései.

Tér és Társadalom 24. évf. 2010/1. 65-81. p.

TÉT XXIV. évf. 2010 घ 1

Az immateriális és a ...

\section{1. ÁBRA}

Az immateriális és gazdasági tóketípusok és átalakulásaik (Intangible and Economic Capital Assets and Transformations)
egyéni szint
kollektiv szint

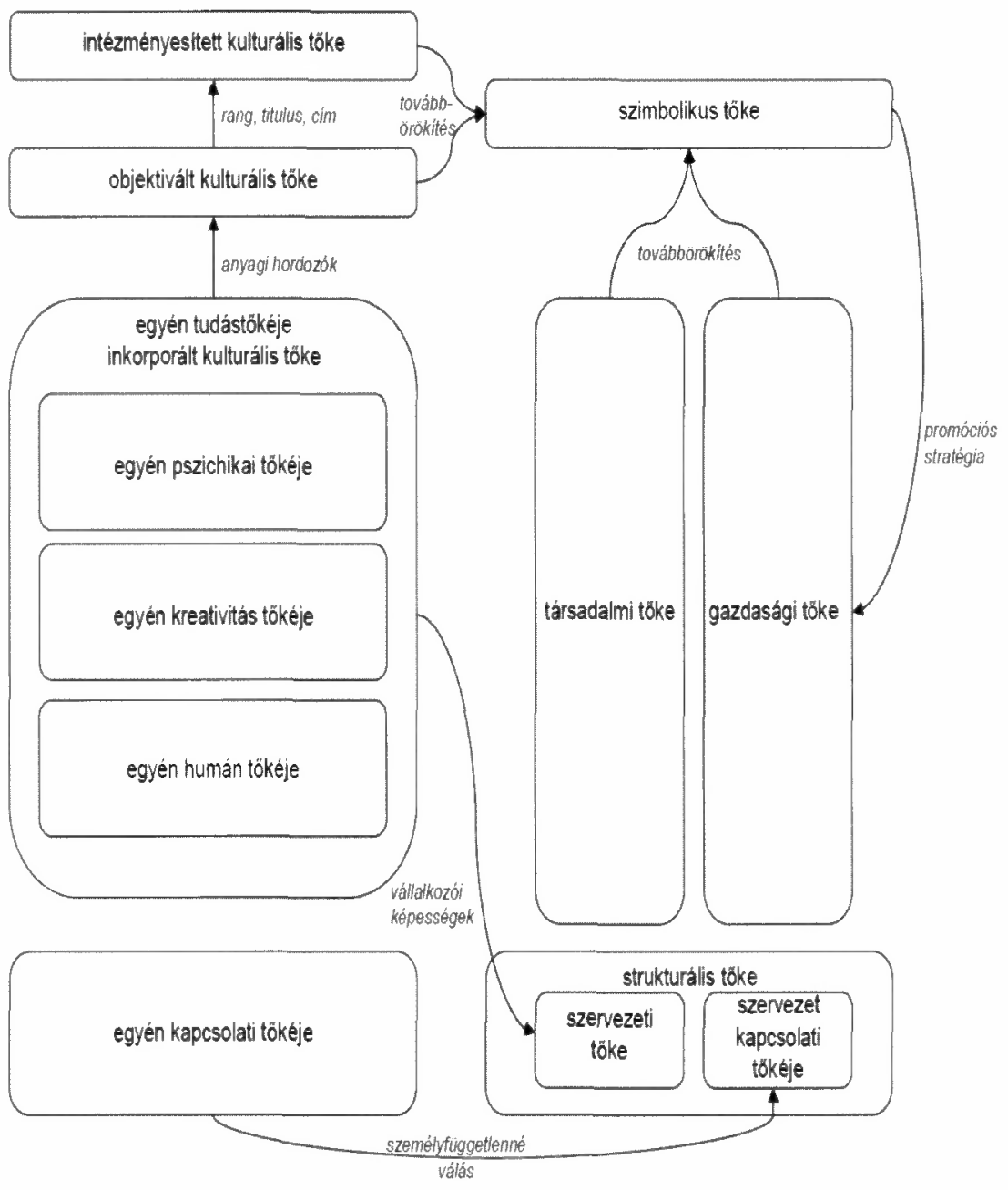

Forrás: Saját szerkesztếs. 
Tóth Balázs István : Az immaterális és a területi tőke összefüggései.

Tér és Társadalom 24. évf. 2010/1. 65-81. p.

\section{2. ÁBRA}

A materiális és immateriális tökeállomány halmazai terïletenként

(Set of Tangible and Intangible Territorial Capital Assets)

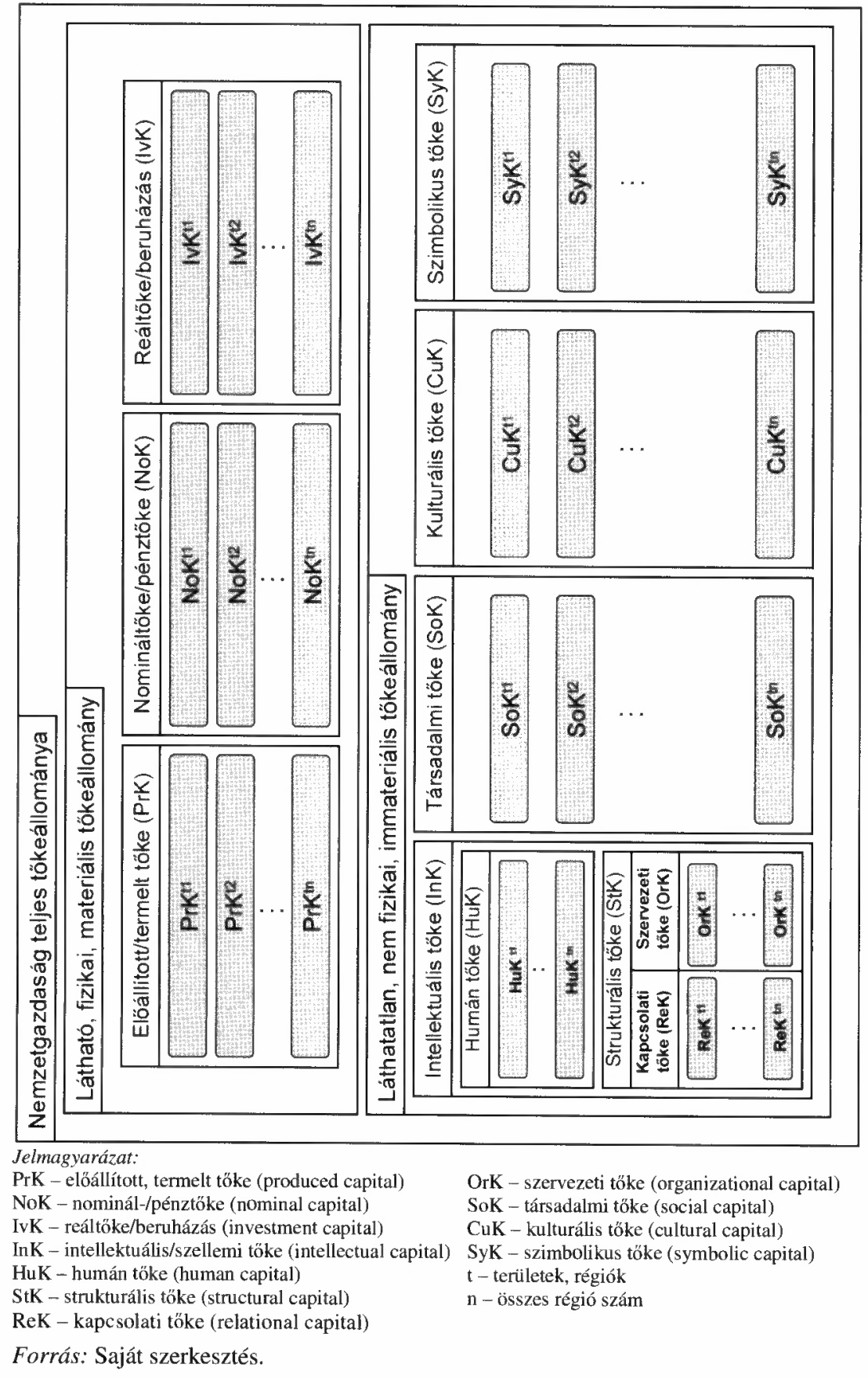




\section{A szükösség fogalmának újraértelmezése}

A közgazdaságtan egyik legfontosabb kérdései közé tartozik a szükös eröforrásokkal való gazdálkodás. A társadalom szükségletei korlátlanok, míg ehhez képest - a klasszikus felfogás szerint - az erőforrások, nyersanyagok, az energia, a képzett munkaerö adott időben szủkös mennyiségben állnak rendelkezésre. Perman és szerzőtársainak munkája (1996), illetve a Világbank Where is the Wealth of Nations? címü dolgozata (2006) új alapot nyújt a szúkösség és a fenntarthatóság fogalmának újragondolásához. Ehhez a koncepcióhoz a fent vázolt modell szervesen beilleszthető.

Míg korábban a fenntarthatóságot az outputok oldaláról vizsgálták a szakemberek, addig napjainkra nagyobb hangsúly helyeződött az input tényezőkre. Perman és társai (1996) munkájukban bemutatják, hogy több teória is született a fenntarthatóság magyarázatára. Az elemzők a fenntartható fejlődés lényegét sokáig az erőforrások és a kibocsátás mennyiségének szinten tartásában $\left(\mathrm{Q}_{1}=\mathrm{Q}_{2}=\ldots=\mathrm{Q}_{\mathrm{n}}\right.$, ahol $Q$ a kibocsátást, $n$ az évek számát jelöli), majd a társadalmi jóléti függvény maximalizálásában $\left(\mathrm{SWF}_{1}=\mathrm{SWF}_{2}=\ldots=\mathrm{SWF}_{\mathrm{n}}\right.$, ahol $\mathrm{SWF}$ a társadalmi jóléti függvényt jelöli $)$ látták. Később már olyan koncepciókat fogalmaztak meg, amelyek azt szorgalmazták, hogy a rendelkezésre álló energiaforrásoknak nem szabad csökkennie $\left(\mathrm{EN}_{1}=\mathrm{EN}_{2}=\ldots=\mathrm{EN}_{\mathrm{n}}\right.$, ahol $E N$ az energiaforrásokat jelöli), így például új energiamezök vagy lelöhelyek feltárásával lehet elkerủlni, hogy a termelés ne csökkenjen. Az 1990-es évekre viszont világossá vált, hogy a klasszikus termelési tényezők (gazdasági tỏke, munka, föld, energia, nyersanyagok stb.) igenis szükösek, s általuk a fenntartható fejlödés nem biztosított. Ugyan az output- és energiaoldali elméletek nem vesztették el létjogosultságukat, a figyelem középpontja egy új erőforrásra helyeződött, méghozzá a tanulmányban vizsgált immateriális vagyonállományra. A Világbank 2006-os jelentése egyértelmúvé teszi, hogy a gazdálkodás egyes formáit a gazdálkodás más eszközeivé lehet, és kell átalakítani, mert ez biztosítja a jövôre nézve a fenntarthatóságot. Ha ezt az egyes országok és régiók nem ismerik fel, akkor a fejlettségbeli különbségek megmaradnak, s az ezredforduló után tovább nő a szakadék a gazdag és szegény országok között, illetve az egyes országokon belül is.

Az országok, nagy- és kisrégiók gazdagsága az új szemlélet szerint a természeti, az elóállított és a láthatatlan tỏke egyensúlyában keresendỏ, mert a természeti és termelt tőke csökkenése pótolható az intangibilis tőke mennyiségének növelésével. Matematikailag a fenntarthatóság ezen kritériuma a következő formában fejezhető ki: Ha $\mathrm{NaK}^{t}$ egy adott területen rendelkezésre álló természeti (natural capital), $\operatorname{Pr} K^{t}$ a termelt (produced capital) és $I t K^{t}$ a láthatatlan tỏkeelemeket (intangible capital) jelöli, akkor az alábbiak szerint írható fel a fenntarthatóság napjainkra elfogadottá vált kritériuma:

$$
\mathrm{NaK}_{1}{ }_{1}+\operatorname{Pr}_{K_{1}}{ }_{1}+I t K^{r}{ }_{1}=\mathrm{NaK}_{2}{ }_{2}+\operatorname{Pr}^{\prime}{ }_{2}+I t K_{2}^{r}=\ldots=N a K_{n}^{r}+\operatorname{Pr}_{2}^{r}{ }_{n}+I t K_{n}^{r} .
$$

Mivel az egyenletben szereplő $\mathrm{NaK}$ tag nagysága a természeti erőforrások egyre nagyobb mértékủ kifosztása miatt az indexszámok növekedésével egyre csökken, s ezt nem kompenzálja a $\operatorname{Pr} K$ tag növekedése - amely egyébként szintén csökkenhet 
recesszió vagy válság esetén -, a harmadik tagnak, azaz az It $K$ növekedésének kell biztosítania a fenntarthatóságot. Az összefüggés alapján könnyen belátható, hogy a láthatatlan töke szerepe - melyet Marshall egyszerüen „environment"-nek nevezett (OECD 2001b) - felértékelödik a nemzet- és regionális gazdaságokban. Nagy jelentőséggel bírnak tehát az intangibilis tőkeelemek, hiszen ezek segítségével hosszú távon biztosítható egy ország vagy egy terület fenntartható fejlődése. A 2. ábrán szereplő immateriális tőkeelemek közötti kapcsolatot a matematikai halmazelmélet jelölései segítségével az alábbiak szerint lehet képletszerüen leírni:

- Az i-edik régió materiális tőkéjét alkotó függvényelemek az alábbiak:

$$
\begin{aligned}
& K_{\text {materiális }}^{i}=\operatorname{Pr} K^{t i} \cup N o K^{t i} \cup I v K^{t i} \\
& K_{\text {materiális }}^{i}=f\left(\operatorname{Pr} K^{t i} ; N o K^{t i} ; I v K^{t i}\right) .
\end{aligned}
$$

- Az i-edik régió immateriális tőkéjét alkotó függvényelemek az alábbiak:

$$
\begin{aligned}
& K_{\text {immateriális }}^{i}=I t K^{t i}=H u K^{t i} \cup \operatorname{Re} K^{t i} \cup \operatorname{Or} K^{t i} \cup \operatorname{SoK} K^{t i} \cup C u K^{t i} \cup S y K^{t i} \\
& K_{\text {immaterialis }}^{i}=I t K^{t i}=f\left(H u K^{t i} ; \operatorname{Re} K^{t i} ; O r K^{t i} ; S o K^{t i} ; C u K^{t i} ; S y K^{t i}\right) .
\end{aligned}
$$

- Az i-edik régió területi tỏkéjét alkotó függvényelemek a következők:

$$
\begin{aligned}
& K^{i}=\operatorname{Pr} K^{t i} \cup N o K^{t i} \cup I v K^{t i} \cup H u K^{t i} \cup \operatorname{Re} K^{t i} \cup O r K^{t i} \cup S o K^{t i} \cup C u K^{t i} \cup S y K^{t i} \\
& K^{i}=f\left(\operatorname{Pr} K^{t i} ; N o K^{t i} ; I v K^{t i} ; H u K^{t i} ; \operatorname{Re} K^{t i} ; O r K^{t i} ; \operatorname{SoK}^{t i} ; C u K^{t i} ; S y K^{t i}\right) .
\end{aligned}
$$

- A teljes nemzetgazdasági területi tỏkeállományt alkotó függvény elemei az alábbiak:

$$
\begin{aligned}
& K=\sum_{i=1}^{n} \operatorname{Pr} K^{i} \cup \sum_{i=1}^{n} N o K \cup \sum_{i=1}^{n} J K \cup \sum_{i=1}^{n} H u K \cup \sum_{i \in}^{n} \operatorname{R} K^{K i} \cup \sum_{i=1}^{n} O r K \cup \sum_{i=1}^{n} S o K^{i} \cup \sum_{i=1}^{n} C u K \cup \sum_{i=1}^{n} S y K
\end{aligned}
$$

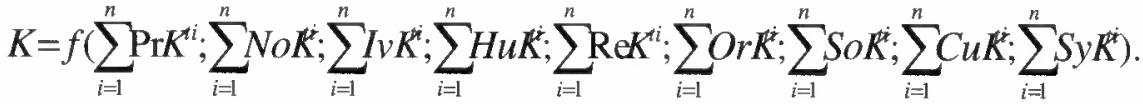

A területi tőke tehát nem illeszthető be a materiális és a tárgyalt immateriális tőketípusok egyszerü folytatásaként, hanem a területi tỏkében $\left(\mathrm{K}^{\mathrm{i}}\right)$ összesítendők a láthatatlan és a fizikai komponensek. Jelen tanulmányban nem foglalkoztunk a tôkeátalakulások részletesebb matematikai hátterével, viszont későbbi kutatási irányként jelöljük meg ennek elemzését. A tökeátalakulások pontos leírása szolgálhat ugyanis egy olyan matematikai bázis megalkotásához, amely közelebb vihet a precízebb kvantitatív mérési lehetőségekhez. 


\section{Összegzés}

A vázolt összefüggések fényében felmerül a kérdés, hogy milyen gyakorlati haszna van a területi tőkére épített elméleteknek. A területi tőkét mind a klaszteresedés, hálózatosodás, mind pedig a területi kohézió (újra)értelemzésének oldaláról lényegesnek tartjuk.

A klaszterek esetében az ún. szellemi tőke jelentések egészítik ki a hagyományos pénzügyi jelentéseket azzal, hogy fizikailag meg nem fogható erőforrásokra (humán tőke, strukturális tőke, kapcsolati tőke) helyezik a hangsúlyt. Az ilyen típusú jelentéseket, mint a magánszektorban alkalmazott menedzsment eszközt az 1990-es évek elején dolgozták ki Svédországban, de a módszertant Európa más területein is átvették, és alkalmazzák. A Ricarda projekt például a szellemi töke jelentés módszertanának a regionális technológiaorientált hálózatokra vonatkozó kísérleti alkalmazását tủzte ki célul négy pilot klaszter segítségével.

A területi töke fogalmának bevezetésével a területi kohézió felfogása is új értelmezést nyerhet. A területi potenciálokra, tỏkére alapozott tervezés ugyanis figyelembe veszi a környezetre, annak minden szegmensére és érintettjére gyakorolt hatását (Illés 2009). A területi tervezés célja nem lehet más, mint az adott térség humán, szervezeti, társadalmi, kulturális és szimbolikus adottságainak legjobb kihasználása a leghatékonyabb területi munkamegosztás keretében. A gazdasági fejlettséget mérö mutatók mellett tehát nélkülözhetetlen más összetevők, fơként az immateriális tényezők számszerüsítése is. A regionális GDP nem lehet a különbségek egyetlen mércéje, mert a régiók GDP-je közelíthet egymáshoz, miközben az emberek és a társadalmak helyzetében való különbségek növekednek. Ennek ellenkezöje is igaz teoretikusan, tehát a társadalmi rendszerek közelíthetnek egymáshoz, miközben a regionális GDP-ben mért különbségek nem csökkennek. Fabrizio Barca 2009 áprilisában készített jelentése - a Barca jelentés - azt állítja, hogy a fejlődést és a hatékonyságot az szolgálja leginkább, ha minden régió adottságait, lehetőségeit, potenciálját, területi tőkéjét a lehetỏ legnagyobb mértékben használjuk fel, és aknázzuk ki. Ez lehetséges akkor is, ha a területi különbségek csökkennek, de akkor is, ha növekednek (Barca 2009; Illés 2009). Hosszabb távon ugyanis nem szuikségszerủ, hogy a különböző régiók egyformán részesedjenek a nemzetközi vagy interregionális kereskedelem növekedésének előnyeiből (Barca 2009). A területi tőke alapú megközelítésekkel rámutathatunk arra, hogy a regionális GDP-ben mért régiók hátránya vagy előnye mégsem pontosan annyi, mint ahogy azt a regionális GDP mutatja.

\section{Irodalom}

Barca, F. (2009) An Agenda for a Reformed Cohesion Policy. A Placed-based Approach to Meeting European Union challanges and expectations. EU, Brüsszel. http://ec.europa.eu/regional_policy/ policy/future/barca_en.htm (Letöltés időpontja: 2009. 10.4.)

Bourdieu, P. (1978) A szimbolikus töke. - Bourdieu, P. (szerk.) A társadalmi egyenlötlenségek újratermelödése. Gondolat, Budapest. 379-400. o. 
Bourdieu, P. (1983) Ökonomische Kapital, kulturelles Kapital, soziales Kapital. - Kreckel, R. (Hrsg.) Soziale Ungleichheiten. Soziale Welt. Sonderband 2. Göttingen. 183-198. o.

Camagni, R. (2008) Regional Competitiveness. Towards a Concept of Territorial Capital. - Capello, R.Camagni, R.-Chizzolini, B.-Fratesi, U. (eds.) Modelling Regional Scenarios for the Enlarged Europe. European Competitiveness and Global Strategies. Springer, Berlin. 33-46. o.

Capello, R.-Faggian, A. (2005) Collective Learning and Relational Capital in Local Innovation Processes. - Regional Studies. 1. 75-87. o.

Catin, M. (2000) Les mécanismes et les étapes de la croissence régionale. - Bulletin de l' économique de la défense. Janvier. Paris

Coleman, J.S. (1988) Social Capital in the Creation of Human Capital. - The American Journal of Sociolog. Supplement. 95-120. o.

Edvinsson, L.-Malone, M.S. (1997) Intellectual Capital. The Proven Way to Establish Your Company's Real Value by Measuring Its Hidden Brainpower. Harper, New York.

Fukuyama, F. (2007) Bizalom. A társadalmi erények és a jólét megteremtése. Európa Könyvkiadó, Budapest.

Hamel, G.P.-Prahalad, C.K. (1990) The Core Competence of the Corporation. - Harvard Business Review. May-June. 79-91. o.

Hennings, K.H. (1987) Capital as a factor of production. - Eatwell, J.-Milgate, M.-Newman, P. (eds.) The New Palgrave: A Dictionary of Economics. Volume 1. 327-330. o.

Illés I. (2009) A területpolitika változási irányai az Európai Unióban. Elöadás. Területfejlesztók Napja, Balatonkenese, 2009. október. http://www.mrtt.hu/konferenciak/teruletfejlesztok/teruletfejlesztok.pdf (Letöltés idöpontja: 2009. 10. 20).

Lin, N. (2001) Social Capital. A Theory of Social Structure and Action. Cambridge University Press, New York.

Machlup, F. (1982) Beruházások az emberi erőforrásokba és a produktív tudásba. - Schmidt Á.Kemenes E. (szerk.) Változások, váltások és válságok a gazdaságban. Tanulmányok Varga István emlékezetére. Közgazdasági és Jogi Könyvkiadó, Budapest. 220-236. o.

Markman, G.D. (2007) Entrepreneurs' Competencies. - Baum, J.R.-Frese, M.-Baron, R. (eds.) The Psychology of Entrepreneurship. Lawrence Erlbaum Associates, New Jersey. 67-92. o.

Mátyás A. (1973) A modern polgári közgazdaságtan története. Közgazdasági és Jogi Könyvkiadó, Budapest.

Mátyás A. (2004a) A korai közgazdaságtan története. Aula Kiadó, Budapest.

Mátyás A. (2004b) A modern közgazdaságtan története. Aula Kiadó, Budapest.

OECD (1996) The Knowledge-based Economy. OECD, Paris. http://www.oecd.org (Letöltés idöpontja: 2009. március 3.)

OECD (2001a) Tudásmenedzsment a tanuló târsadalomban. Oktatás és készségek. OECD, Paris. http://www.oecd.org

OECD (2001b) Territorial Outlook. OECD, Paris.

Perman, R.-Ma, Y.-McGilvray, J. (1996) Natural and Environmental Resource Economics. Longman, London.

Putnam, R.D. (1993) The Prosperous Community - Social Capital and Public Life. - The American Prospect. 4. 27-40. o.

Schultz, T.W. (1983) Beruházás az emberi tókébe. Közgazdasági és Jogi Könyvkiadó, Budapest.

Skandia AFS. (1995) Human Capital in Transformation, Intellectual Prototype Report. Skandia AFS, Stockholm. http://www.skandia-afs.com (Letöltés idópontja: 2009. október 9.)

Sprenger, R.U. (2001) Inter-firm Networks and Regional Networks. ADAPT, Bonn.

Stehr, N. (2002) Knowledge \& Economic Conduct. University of Toronto Press, Toronto.

Stewart, T. (1997) Intellectual Capital. Doubleday/Currency. New York.

Storberg, J. (2002) The Evolution of Capital Theory. A Critique of a Theory of Social Capital and Implications for HRD. - Human Resource Development Review. 1. 468-499. o.

Sveiby, K.E. (1997) The New Organizational Wealth: Managing and Measuring Knowledge-Based Assets. Berett-Koehler Publishers, San Fransisco.

Tomer J.F. (1987) Organizational Capital: The Path to Higher Productivity and Well-Being. Praeger Publishing Co., New York.

Worldbank (2006) Where is the Wealth of Nations? Measuring Capital for the 21th Century. Világbank, Washington D.C. 


\section{CONNECTION BETWEEN INTANGIBLE AND TERRITORIAL CAPITAL}

\section{BALÁZS ISTVÁN TÓTH}

Capital assets are important resources for economic activity. Experts from different scientific fields have been dealing with creating new capital forms since the 1980's. The less measurable, so called intangible capital assets can be widely observed on a large scale. The author of the study focuses on the separation of non-physichal capital forms on individual and collective level, the transformation process of capital assets and the intersections between intangible and territorial capital. The main purpose of the study is to create a model that helps understanding the existing capital forms better and to define the intersection point between immaterial and territorial elements. In the study the author takes different concepts of capital assets over fields, like economy, sociology, and psychology to give a more complex picture of the analysed questions. In the essay the author is dealing with redefinition of tightness, too, and the imporance of intangible capital in the development process of a country or a region is being stressed by new models. 